\title{
AEROBIC POLLUTION ABATEMENT OF PULP MILL EFFLUENT WITH THE WHITE ROT FUNGUS phanerochaete chrysosporium IN THREE-PHASE FLUIDIZED BED BIOREACTOR
}

\author{
B. Jaganathan, SK Masud Hossain, K. M. Meera Sheriffa Begum, N. Anantharaman* \\ Department of Chemical Engineering, National Institute of Technology, Tiruchirappalli - 620 015, Tamil Nadu, India
}

Received 6 June 2009; received in revised form 7 July 2009

\begin{abstract}
The ligninolytic fungus Phanerochaete chrysosporium was used to treat the pulp and paper-mill effluent. It was pelletized and used for batch and continuous experiments in a two-liter fluidized bed bioreactor. The continuous experiment was initiated with concentrated effluent without any extra carbon source and the average removal of color was 3.8\%. Then, it was fed with $50 \%$ diluted effluent which was enriched with glucose. At first, the glucose was consumed by the fungus, which is indicated by a COD removal of $38.5 \%$ and a $26.5 \%$ removal of color. This indicates the need for an extra carbon source for the fungal treatment. Using the mycelial mass in suspension, two experiments were carried out. The best results were obtained with $20 \%$ fungus and shaking of the effluent. During the last three days of the experiment using the mycelium mass the average removal of color, COD and BOD was $86.4 \%, 78.8 \%$ and $70.5 \%$, respectively. The result indicates the potential of Phanerochaete chrysosporium for use in the treatment of pulp and paper-mill effluent.
\end{abstract}

Keywords: Pulp and paper-mill effluent, fungal treatment, Phanerochaete chrysosporium

DOI:10.3329/cerb.v13i1.2613

\section{Introduction}

Bleached kraft pulp and paper mills produce large quantities of brown colored effluents as a result of different processes applied to wood and pulp. These effluents contain many chlorinated organic compounds, which are responsible for their brown color and originate in the residual lignin degradation during the process of bleaching the pulp $[1,2]$.

These effluents are usually treated in aerated lagoons and activated sludge is treated by biological processes which reduce the chemical oxygen demand (COD) and the biological oxygen demand (BOD) but are not efficient in reducing color [3].

Many studies have demonstrated that the color of kraft effluents can be reduced by white-rot fungi, which are considered promising for the treatment of these effluents [1-3]. A process that has been extensively studied is the Mycor (Mycelial Color Removal) process, which uses phanerochaete chrysosporium. Burds immobilized this on rotary biological contactor (RBC) [1]. Pellinen et al. [4] used this process and obtained decolorization and $33 \%$ COD reduction in two days, using mineral and nutrient solution in addition to $10 \mathrm{~g} / \mathrm{L}$ of glucose.

In search for more efficient and economically practicable processes, other bioreactor and ligninolitic fungi

*Corresponding author Email: naramanrect@yahoo.co.in, naraman@nitt.edu; Ph: 91-431-2503103 Fax:91-431-2500133 have been studied. Cammarota [3] used the same fungus immobilized on polyurethane foam in a fixed-bed bioreactor. He used diluted effluent with nutrients and obtained $70 \%$ decolorization, and a $50 \%$ average reduction of COD. The average hydraulic retention time of the reactor was 5.8 days.

The fixed-bed bioreactor was also used by Esposito et al.[1]. The effluent was treated by Lentinus edodes immobilized on nylon and on wood under a batch system. After $120 \mathrm{~h}$ of experiment, using the fungus immobilized on nylon, there was $70 \%$ decolorization and a $67 \%$ reduction of COD.

In the present work, the fungus phanerochaete chrysosporium was used. It was pelletized and used in fluidized bed bioreactor for removal of color, COD and BOD from the effluent from a kraft pulp and paper mill. Its mycelial mass, which was not pelletized, was used in batch experiments to treat the same effluent.

\section{Methods}

\subsection{Microorganism and Media}

Phanerochaete chrysosporium was provided by NCIM culture collection and the stock culture was maintained on PDA (potato-dextrose-agar) medium at $5^{\circ} \mathrm{C}$. Fungus, which was grown at PDA for seven to ten days, was inoculated in $30 \mathrm{~mL}$ tubes containing $10 \mathrm{~mL}$ of liquid medium (potato-dextrose). After seven to ten days, the mycelial mass and medium were transferred (C)Bangladesh Uni. of Engg. $\mathcal{G}$ Tech. 
to $250 \mathrm{~mL}$ conical shake flasks, which contain $90 \mathrm{~mL}$ of liquid medium. Flasks were shaken for seven days at $120 \mathrm{rpm}$ and $30^{\circ} \mathrm{C}$ to form the pellets. The flasks were also incubated at $30^{\circ} \mathrm{C}$ without shaking for five days only to form the mycelial mass.

\subsection{Effluent and Reactor}

The effluent obtained from a kraft pulp and papermill was filtered through a $0.5 \mathrm{~mm}$ sieve to remove large suspended particles and stored at $-5^{\circ} \mathrm{C}$ until use. The characteristics of collected sample were 838.02 $\mathrm{mg} / \mathrm{L} \mathrm{COD,} 700.3 \mathrm{mg} / \mathrm{L} \mathrm{BOD}, 9.5 \mathrm{pH}$ and $250 \mathrm{CU}$ color.

The reactor was a $2000 \mathrm{~mL}$ acrylic column. Aeration and mixing were carried out by a diffuser placed at the bottom of the column. The flow rate of the compressed air to the diffuser, which was regulated by a rotametre, was $0.6 \mathrm{~L} / \mathrm{min}$. The reactor was fed at the bottom by a pump and the effluent in the reactor was maintained at ambient temperature.

\subsubsection{Continuous Bioreactor}

After filtration, the pellets were aseptically inoculated in the reactor at a proportion of $10 \%$ of the reactor volume. After a $48 \mathrm{~h}$ inoculation, the reactor was fed continuously and effluent samples were taken every $24 \mathrm{~h}$ at the inlet and outlet of the bioreactor. Two types of experiments were done. The one considering the age of inoculum and with the addition of glucose and the other in which the column was fed with effluent at different dilutions and concentration of glucose. The effluent sample was taken and analyzed for color, COD and of BOD. The hydraulic retention time of the experiment was eight hours.

\subsubsection{Batch Bioreactor}

After being filtered, the mycelial mass was inoculated in the effluent according to the condition shown in the batch bioreactor. The experiments were carried out for five days in $500 \mathrm{~mL}$ beaker containing $500 \mathrm{~mL}$ of effluent at ambient temperature. The mixed effluent was mixed by magnetic shaker. The $\mathrm{pH}$ was adjusted to a range of 6 to 7 . Throughout the experiment, $15 \mathrm{~mL}$ samples were collected every $24 \mathrm{~h}$ for the analysis of $\mathrm{pH}, \mathrm{COD}$ and BOD.

\section{Analytical Method}

Determination of chemical oxygen demand (COD) was carried out by the APHA standard micro-method, adapted by Tavares et al.[5]. Color was measured as absorbance in platinum cobalt units at $465 \mathrm{~nm}$ and $\mathrm{pH}$ 6.7, as described by Esposito et al.[1]. pH was measured using a digital potentiometer.
Table 1: Experimental conditions and results obtained throughout the continuous experiments

\begin{tabular}{|c|c|c|c|c|}
\hline \multirow[t]{2}{*}{$\begin{array}{l}\text { Experiment } \\
\text { Days }\end{array}$} & \multirow[t]{2}{*}{$\begin{array}{l}\text { Reactor } \\
\text { Feed }\end{array}$} & \multirow{2}{*}{$\begin{array}{l}\text { Reactor } \\
\text { Effluent } \\
\text { pH }\end{array}$} & \multicolumn{2}{|c|}{$\begin{array}{c}\text { Average } \\
\text { removal } \%\end{array}$} \\
\hline & & & Color & COD \\
\hline $1 \mathrm{st}-2 \mathrm{nd}$ & $\mathrm{CE}^{\mathrm{a}}$ & 7 & 3.8 & - \\
\hline $3 \mathrm{rd}-5$ th & $\mathrm{DE}^{\mathrm{b}}$ & 8.4 & - & 12.5 \\
\hline 6 th- 7 th & DE-10 $10^{c}$ & 5.7 & 26.5 & 38.5 \\
\hline 8th-10th & $\mathrm{DE}-10^{\mathrm{c}}$ & 3.9 & 82.5 & 78.4 \\
\hline
\end{tabular}

${ }^{\mathrm{a}}$ Concentrated effluent ${ }^{\mathrm{b}} 50 \%$ diluted effluent

${ }^{\mathrm{c}}$ glucose concentration $(\mathrm{g} / \mathrm{L})$

\section{Results and Discussion}

The first experiment (Table 1) was initiated with concentrated effluent without any extra carbon source. There was $\mathrm{pH}$ neutralization and average removal of color was $3.8 \%$. Then, it was fed with $50 \%$ diluted effluent which was enriched with glucose. At first, the glucose was consumed by the fungus, which is indicated by a COD removal of $38.5 \%$ and then there was a $26.5 \%$ removal of color. The diluted effluent without glucose was again fed into the reactor and performance of fungus was worse than the previous one.

Results of the continuous experiment indicated that the feed of concentrated effluent damaged the performance of the fungus despite the addition of glucose to the effluent.

In the second experiment, effect of treatment time and inoculum age is studied. From Figure 1 and 2, it is clear that the COD and BOD levels reduced considerably with increase in time. As the age of inoculum increases, the COD and BOD reduction rates also increase, when all the other parameters (diameter of the packing, retention time) remain constant. The reduction in COD and BOD are $75.58 \%$ and $64.48 \%$ after 8 hours of treatment time with inoculum age of 3 days respectively. The reduction in COD and BOD are $79.56 \%$ and $75.54 \%$ after 8 hours of treatment time with inoculum age of 5 days respectively. The reduction in COD and BOD are $83.52 \%$ and $81.04 \%$ after 8 hours of treatment time with inoculum age of 7 days respectively.

The result of the batch experiment indicated that the best treatment using the fungus in suspension was the second one (Table 2). Due to the shaking used during this experiment, the entire mycelial mass was fragmented. The small particles were maintained in suspension by the shaking to avoid sedimentation. This fragmentation of the mycelial mass, which increased the area of contact between the effluent and oxygen, and the amount of fungus, was probably responsible for these results being the best.

The decolorization results obtained with phanerochaete chrysosporium in suspension under the conditions of the second experiment were better than the 


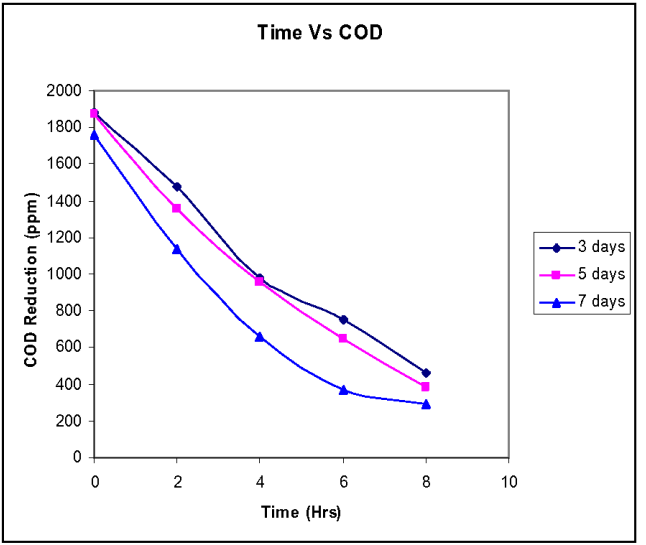

Figure 1: COD reduction

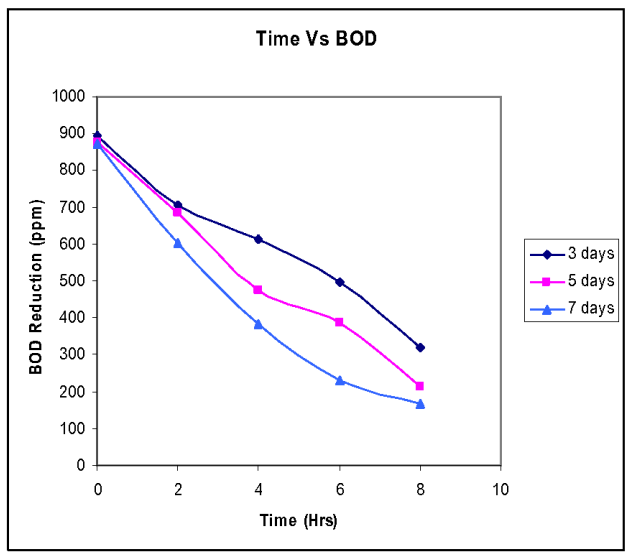

Figure 2: BOD reduction

Table 2: Experimental conditions and results obtained in the batch experiments

\begin{tabular}{l|c|c}
\hline Experiments & First & Second \\
\hline Mycelial mass & $10 \%$ & $20 \%$ \\
(on reactor volume) $(\% \mathrm{v} / \mathrm{v})$ & & \\
Shaking & No & Yes \\
$\mathrm{pH}$ & 4.8 & 3.9 \\
color removal $(\%)^{3}$ & 32.9 & 86.4 \\
COD removal $(\%)^{3}$ & 27.3 & 78.8 \\
BOD removal $(\%)^{3}$ & 38.8 & 70.5 \\
\hline
\end{tabular}

${ }^{3}$ After the third day result obtained with other fungi. Esposito et al. [1] obtained $73 \%$ color removal after five days of treatment. The authors used diluted effluent without extra carbon source and the fungus Lentinus edodes. Using Coriolus versicolor, livernoche et al. [6] obtained 60\% decolorization using the fungus in liquid culture, and $80 \%$ with the fungus immobilized on calcium alginate. They used effluent enriched with glucose. The results obtained during that experiment were also better than the ones obtained by Archibald et al. [7]. The authors used coriolus versicolor and E1 effluent with $20 \mathrm{mM}$ of glucose, obtaining $80 \%$ decolorization. The decolorization results of the second experiment are comparable to those obtained by Wang et al. [8], who used the fungus Ganoderma lacidum. In their experiments Livernoche et al. [6] and Archibald et al. [7] used in their experiments the fungi cultivated in media enriched with nutrients and glucose. In addition to the medium enriched with nutrients, Wang et al. [8] used effluent diluted and enriched with nutrients and glucose.

For the experiments using the fungus in suspension, concentrated effluent was used without addition of an extra carbon source or nutrients and the fungus was cultivated in PDA without the addition of nutrients. Considering these facts, the results obtained in this study were better than those obtained in others.

\section{Conclusion}

According to the results obtained during the continuous experiments, an extra carbon source must be added to the effluent and the effluent must be diluted. Thus, the process of reduction of color, of COD and of BOD was better developed when the effluent was diluted and enriched with glucose. The efficient treatment of the pulp and paper-mill effluent by Phanerochaete chrysosporium occurred in acid medium. For the batch and continuous experiments, the $\mathrm{pH}$ was between 3.9 and 5.0 during the periods of efficient treatment. Using the mycelial mass in suspension, the best results were obtained with the largest quantity of glucose and with the shaking of the effluent, which caused fragmentation of the mycelial mass and better contact of the effluent with oxygen. The recommended optimum time is 8 hours. It was necessary to adjust the initial $\mathrm{pH}$ of the effluent. All these results point to the potentiality of Phanerochaete chrysosporium to treat the effluent from pulp and paper mills. It is easy to cultivate and special conditions are not needed. This fact makes it potentially applicable to the control of pollution. This project, however, needs further confirmation and optimization of the treatment process. 


\section{References}

[1] Esposito E, Canhos V and Durn N, Screening of lignindegrading fungi for removal of color from Kraft mill wastewater with no additional extra carbon-source, Biotechnology Letters, 1991. 13(8):pp. 571-576. doi : 10.1007/BF01033412

[2] Prouty AL, Bench-scale development and evaluation of a fungal bioreactor for color removal from bleach effluents, Applied Microbiology and Biotechnology, 1990. 32(4):pp. 490493. doi:10.1007/BF00903789

[3] Cammarota MC, Avaliacao de um bio-reator fungico para remocao de cor do efluente do branqueamento de polpa kraft, Master's thesis, ESCOLA DE QUIMICA/UFRJ, Rio de Janeiro, RJ, 1991

[4] Pellinen J, Joyce T and Chang H, Dechlorination of highMolecular-Weight Chlorolignin by the White-rot Fungus P. chrysosporium, Tappi journal, 1988. 71(9):pp. 191-194

[5] Tavares C, Sant'Anna G and Capdeville B, The effect of air superficial velocity on biofilm accumulation in a three-phase fluidized-bed reactor, Water Research, 1995. 29(10):pp. 22932298. doi : 10.1016/0043-1354(95) 00043-K

[6] Livernoche D, Jurasek L, Desrochers M, Dorica J and Veliky IA, Removal of color from kraft mill wastewaters with cultures of white-rot fungi and with immobilized mycelium of Coriolus versicolor, Biotechnology and Bioengineering, 1983. 25(8):pp. 2055-2065. doi:10.1002/bit.260250814

[7] Archibald F, Paice M and Jurasek L, Decolorization of kraft bleachery effluent chromophores by Coriolus(Trametes) versicolor, Enzyme and Microbial Technology, 1990. 12(11):pp. 846-853. doi:10.1016/0141-0229(90) 90021-H

[8] Wang T, Wang J, Yang W and Jin Y, Experimental study on bubble behavior in gas-liquid-solid three-phase circulating fluidized beds, Powder Technology, 2003. 137(1):pp. 83-90. doi : $10.1016 / j$. powtec .2003 .08 .032 